\title{
Effect of technological treatment on soybean protein rumen degradability ${ }^{*}$
}

\author{
S Puppo ${ }^{1}$, S Terramoccia ${ }^{1}$, A Mordenti $^{2}$, F Martillotti ${ }^{1}$ \\ ${ }^{1}$ Istituto Sperimentale per la Zootecnia, Via O Panvinio 11, 00162 Rome; \\ ${ }^{2}$ Istituto di Zootecnia e Nutrizione Animale, Via S Giacomo 11, 40126 Bologna, Italy
}

As soybean production is very high (about $1500000 \mathrm{mt} / \mathrm{year}$ ) in Italy, many technological treatments are carried out in order to use it for oil extraction and also in dairy cow feeding, as an energy and protein supplement. Our aim was to verify whether different treatments (extruding, flaking, roasting) modified the rumen degrability kinetics of soybean protein.

The study examined the following samples ( $3 \mathrm{~g}$, ground $1 \mathrm{~mm}$ ) : full fat soybean (FFSB), extracted soybean meal (ESBM), extruded soybean (ETSB), flaked soybean (FSB), $1 \mathrm{~h}$ roasted soybean (RSB1), $7 \mathrm{~h}$ roasted soybean (RSB7), $12 \mathrm{~h}$ roasted soybean (RSB12). Nylon bag $(16 \times 10 \mathrm{~cm}$, diam $41 \mu \mathrm{m})$ incubation was carried out on 3 fistulated cows $(3 \times 3$ replications, fed at maintenance level, $80 \%$ maize silage - $20 \%$ grass hay) at $0,1,2,4,8,12,16,24,48$, $72 \mathrm{~h}$, according to Ørskov and McDonald (1979). Kinetics of rumen protein degradability $(k=0.05)$ were computed by the Nocek and English (1986) procedure.

All soybean taken into account showed a variable delay before degradation started (lag time) as compared to full fat soybean. In the case of RSB, the lag phase increased with the roasting time while the zero time a lowered. ESBM showed a lag phase of $3.3 \mathrm{~h}$ but $a, b$ and $c$ parameters were very close to the FFSB corresponding ones. The extruding treatment lowered the protein solubility at zero time $a$ and the degradation rate was slow $(c=0.057)$ in spite of the high value of $b$. Flaking treatment, as compared to the other methods, had a lower effect on the protein solubility, increasing both $a$ and $c$ values. As a consequence, the DT\% values had a different behaviour depending on the treatment and the difference in $\%$ increased according to the time and the type of treatment.

For the same period in the rumen, treated protein compared to untreated protein showed a lag phase and was less degraded, so that a higher amount of dietary protein could escape rumen degradation. Technological treatment is useful for an improvement in protein utilization in feeding of ruminants.

Nocek JE, English JE (1986) J Dairy Sci 69, 77-87

Ørskov ER, McDonald I (1979) J Agric Sci Camb 92, 499-503

Table I. Statistics of untreated and treated soybean.

\begin{tabular}{lcccccccc}
\hline Feed & Lag $(h)$ & $\mathrm{a}$ & $\mathrm{b}$ & $\mathrm{c}$ & $\mathrm{R}^{2}$ & $R S D$ & DT(\%) & Diff \% \\
\hline FFSB & - & 24.4 & $\mathbf{7 4 . 8}$ & 0.075 & 0.97 & 6.7 & 69 & - \\
ESBM & 3.3 & 24.8 & 74.9 & 0.070 & 0.96 & 6.2 & 62 & -10.1 \\
ETSB & 2.7 & 12.3 & 87.6 & 0.057 & 0.92 & 8.7 & 53 & -23.2 \\
FSB & 5.2 & 30.6 & 68.5 & 0.183 & 0.97 & 4.3 & 72 & \pm .3 \\
RSB1 & 4.8 & 19.1 & 80.4 & 0.092 & 0.99 & 1.1 & 60 & -13.0 \\
RSB7 & 5.8 & 9.9 & 86.6 & 0.035 & 0.90 & 9.7 & 37 & -46.4 \\
RSB12 & 12.2 & 6.1 & 35.7 & 0.028 & 0.86 & 5.7 & 13 & -81.2 \\
\hline
\end{tabular}

" Research supported by MPI $40 \%$ project "Protein evaluation in feeding of ruminants." 